\title{
Indigenous pharmaceutical assistance and the scientific silence: a review of the
}

\section{literature}

\author{
Assistência farmacêutica indígena e o silêncio científico: uma revisão da literatura \\ Asistencia farmacéutica indígena y silencio científico: una revisión de la literatura
}

Received: 09/07/2021 | Reviewed: 09/15/2021 | Accept: 09/26/2021| Published: 09/27/2021

\author{
Edson Oliveira Pereira \\ ORCID: https://orcid.org/0000-0002-8933-8141 \\ University of Brasília, Brazil \\ E-mail: edsondirec@gmail.com \\ Bernardino Vitoy \\ ORCID: https://orcid.org/0000-0002-2933-4114 \\ Pan American Health Organization, Brazil \\ E-mail: vitoyber@paho.org \\ Daniel Ignacchiti Lacerda \\ ORCID: https://orcid.org/0000-0002-3151-8879 \\ Várzea Grande University Center, Brazil \\ E-mail: daniel.ignacchiti@gmail.com \\ Damaris Silveira \\ ORCID: https://orcid.org/0000-0003-1851-5224 \\ University of Brasília, Brazil \\ E-mail: damaris@unb.br
}

\begin{abstract}
Although the importance of Pharmaceutical Assistance, there is no global instrument that specifically justifies its necessity on the specificity of indigenous health. This article lists existing studies on pharmaceutical assistance in an indigenous context. It has a qualitative character, conducted through an integrative literature review. National and international databases were consulted for the scientific articles searching, using specific descriptions of the object of interest. Three thousand nine hundred fifteen articles were found in the databases searched, related to the object of interest, in this case, Indigenous Pharmaceutical Assistance. Many studies did not have any relation with the object of interest, and most of them aimed to understand, from the conventional biomedical perspective, the mechanisms of the therapeutic resources of the indigenous people in the world, as well as to investigate scientifically plant and animal materials used in the indigenous traditional medicine, by using known conventional methodologies. A range of studies has addressed specifically illnesses through case studies, in which the focus is the evolution of the disease or western therapy were applied to the indigenous subject, in a research form that tries to indicate different clinical responses to the treatment and the outcome of the pathology. Researches involving planning, implementation, development, and evaluation of Indigenous Pharmaceutical Assistance are crucial for the future development of global policies for these people.

Keywords: Indigenous pharmaceutical services; Health of the indigenous population; Indigenous health policies; Indigenous health.

\section{Resumo}

Apesar da importância da Assistência Farmacêutica, não existe instrumento global que justifique especificamente a sua necessidade de adequação às especificidades dos povos indígenas. Assim, o presente artigo visa enumerar os estudos existentes sobre Assistência Farmacêutica num contexto indígena, com base em uma pesquisa qualitativa, por meio de uma revisão integrativa da literatura. Nesse sentido, foram consultadas bases de dados nacionais e internacionais, utilizando descrições específicas do objeto de interesse nesse caso, a Assistência Farmacêutica Indígena. Foram encontrados 3.915 artigos, dos quais muitos estudos não tinham qualquer relação com o objeto de interesse e a maioria deles procurava compreender, do ponto de vista biomédico convencional, os mecanismos dos recursos terapêuticos dos povos indígenas no mundo, bem como pesquisar os materiais vegetais e animais utilizados na medicina tradicional indígena, por meio de metodologias convencionais conhecidas. Uma série de estudos abordou especificamente os agravos de saúde, por meio de estudos de casos, nos quais o foco principal foi a evolução da doença ou a terapia ocidental aplicada ao sujeito indígena, numa forma de investigação que tenta evidenciar diferentes respostas clínicas ao tratamento e ao resultado da patologia. As investigações que envolvem planeamento, implementação, desenvolvimento e avaliação da Assistência Farmacêutica
\end{abstract}


Indígena são cruciais para o futuro desenvolvimento de políticas globais para estaspessoas, e precisam de ser abordadas num contexto intercultural.

Palavras-chave: Serviços farmacêuticos indígenas; Saúde da população indígena; Políticas de saúde indígena; Saúde indígena.

\section{Resumen}

A pesar de la importancia de la Asistencia Farmacéutica, no existe ningún instrumento global que justifique especificamente su necesidad de forma adecuada y construida sobre las especificidades indígenas. El presente artículo pretende enumerar los estudios existentes sobre la Asistencia Farmacéutica en el contexto indígena. Tiene un carácter cualitativo, realizado a través de una revisión bibliográfica integradora. Para la búsqueda de artículos científicos, se consultaron bases de datos nacionales e internacionales, utilizando descripciones específicas del objeto de interés. Se encontraron 3.915 artículos, en las bases de datos buscadas, relacionados con el objeto de interés, en este caso, la Asistencia Farmacéutica Indígena. Muchos estudios no tenían relación con el objeto de interés y la mayoría busca entender, desde el punto de vista biomédico, los mecanismos de los recursos terapéuticos de los pueblos indígenas en el mundo, así como investigar científicamente materialesvegetales y animales utilizados por ellos mismos, por medio de metodologías convencionales conocidas. Una serie de estudios han abordado específicamente enfermedades, a través de estudios de casos, en los que el enfoque principal es la evolución de la enfermedad o la terapia occidental se aplicaron al sujeto indígena, en una forma de investigación que trata de evidenciar diferentes respuestas clínicas al tratamiento y el resultado de la patología. Las investigaciones que involucran la planificación, implementación, desarrollo y evaluación de la Asistencia Farmacéutica Indígena son cruciales para el futuro desarrollo de políticas globales para estos pueblos, y necesitan ser abordadas; además de las mayoresdemandas de formación profesional adecuada para los profesionales de la salud en un contexto intercultural.

Palabras clave: Servicios farmacéuticos indígena; Salud de la población indígena; Políticas de salud indígena; Salud indígena.

\section{Introduction}

The 400 million indigenous peoples worldwide represent a wealth of linguistic and cultural diversity, as well as traditional knowledge and sustainable practices that are invaluable resources for human development. These indigenous peoples are an important pillar of this diversity, especially in the cultural field, as their knowledge and practices contribute to the formation of the current model of societies. Even though they are under constant pressure to integrate with hegemonic, Western culture, and many of them have been devastated, these practices and knowledge. However, indigenous populations remain on the margins of society in high-, middle-, and low-income countries and have a disproportionate burden of poverty, disease, and mortality compared to the general population, with a scenario of growing inequality around the world (Hernández et. al., 2017).

As a reactionary process of the contemporary trend to accommodate indigenous culture into civilized society, international organizations have composed a short legal framework that supports indigenous peoples in their choices and perpetuates their ancestors' habits and values (ILO, 1989; UN, 2007). The Convention 169 on Indigenous and Tribal Peoples of 1989, signed by the International Labor Organization, recognized for the first time the rights of the indigenous collective, and it is considered the first global conquest for the rights of indigenous peoples. Moreover, the publication of the United Nations Declaration on the Rights of Indigenous Peoples (UNIDRIP), twenty-eight years later, represents a milestone in the international defense of these peoples by ensuring that their fundamental rights were protected from the interests of States against the setbacks of economic interests or different social strata (UN, 2007).

Although its practice in the States has not been effective, the benefits of the publication of the Universal Declaration of Indigenous Rights are undeniable. In Article 21, for example, the implementation of improvements is determined, mainly against discrimination in various sectors, including health, and in Article 23, the right to determine priorities and develop strategies for the community development, especially in the active participation, by the indigenous representatives, in the design and determination of health programs (UN, 2007). Thus, this UN Declaration can be considered the largest global instrument for protecting Indigenous Peoples' health, mainly because it highlights the need to develop and implement policies to protect and promote indigenous peoples' 
rights at regional levels around the world,, replacing integrationist and assistentialist policies. Even so, it is possible to evidence the lack of a mechanism that effectively ensure the exercise of the rights already consecrated.

The Brazilian Ministry of Health understands that Pharmaceutical Assistance concerns several activities related to drugs and medicines that support the health service demanded by the community. These activities concern the drug logistic cycle stages, such as production, storage, quality control, safety and therapeutic efficacy of medicines; monitoring and evaluation of use; supply and dissemination of information on drugs and the continuing education of health professionals, patients, and the community, to ensure the rational use of medicines (Brazil, 1998).

Despite the importance of Pharmaceutical Assistance, there is no global instrument that justifies the need for a specific Pharmaceutical Assistance branch adjusted to the indigenous peoples specificities. Little is said about Indigenous Pharmaceutical Assistance in regional or a global context. Considering the need to awaken such a relevant theme and the additional challenges to those encountered in implementing conventional Pharmaceutical Assistance adopted by the biomedical model, this article lists existing information on Pharmaceutical Assistance in the indigenous context.

\section{Methodology}

This study was carried out in a qualitative way, conducted through an integrative literature review. For the search of scientific articles, national and international databases of the health area were consulted with electronic access, such as MEDLINE, Virtual Health Library-BVS, LILACS, and SCIELO. The articles were selected by title and abstract, according to the descriptors "Indigenous Pharmaceutical Assistance," "Indigenous Health Medicine," "Indigenous Pharmaceutical Assistance Policy," and "Indigenous Pharmaceutical Service" used in English and Portuguese, without applying filters of time and type of study.

Duplicate production and studies that did not have abstracts or available complete text platforms were excluded, in addition to those that were not related to the defined topic. The selected studies are sorted in a table according to reference, general objective, and conclusions. This table was the instrument used to systematize the data.

Figure 1: Summary of the method used to include the scientific production about Indigenous Pharmaceutical Assistance according to the used criteria

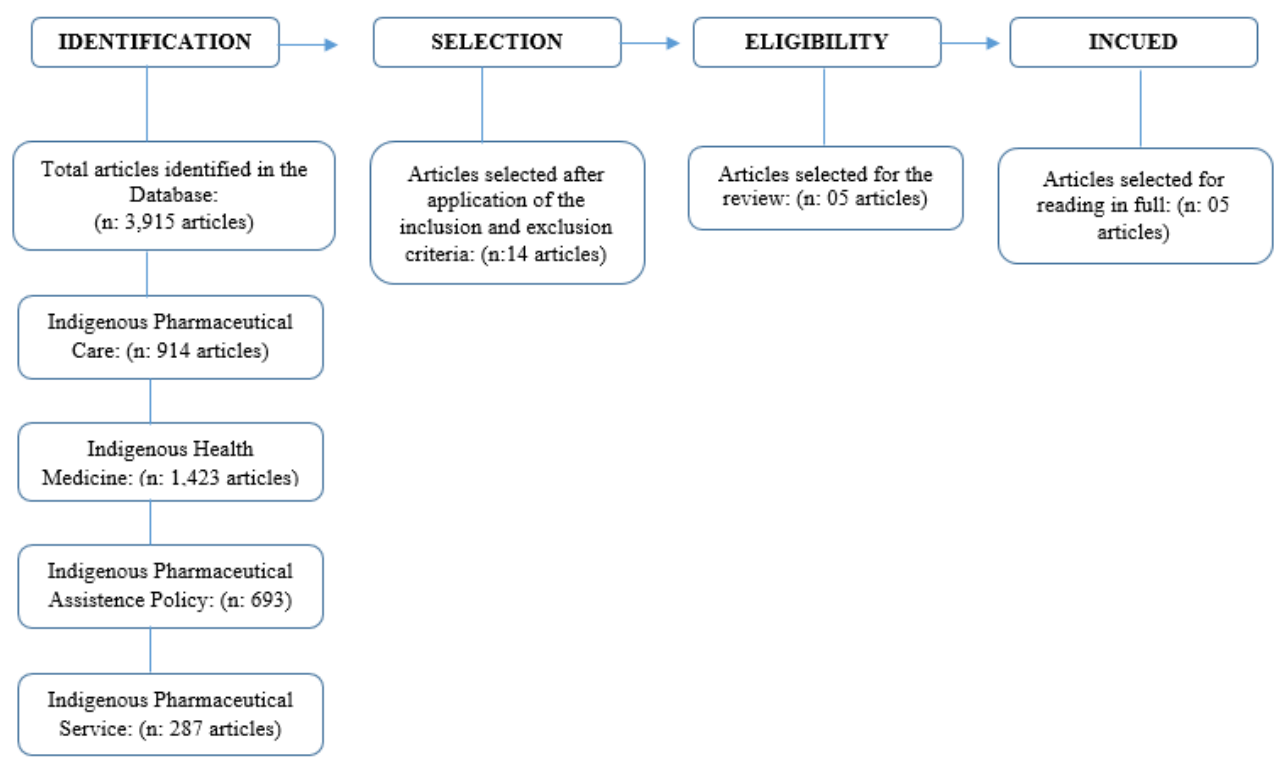

Source: Authors. 


\section{Results and Discussion}

An amount of 3,317 articles related to the object of interest was found in the searched databases. Among them, only five presented some relation with the object of interest, considering the methodological criteria

Table 1: Summary of the articles about Indigenous Pharmaceutical Assistance included in the review.

\begin{tabular}{|c|c|c|}
\hline REFERENCE & MAIN SUBJECT & CONCLUSIONS \\
\hline $\begin{array}{l}\text { ROMAIN, S.J. (2013) } \\
\text { "Pharmaceutical Health Care } \\
\text { and Inuit Language } \\
\text { Communications in Nunavut, } \\
\text { Canada". }\end{array}$ & $\begin{array}{l}\text { Examines the complex issues } \\
\text { associated with one component of } \\
\text { Aboriginal healthcare: } \\
\text { communication between the Inuit } \\
\text { of Nunavut, Canada. }\end{array}$ & $\begin{array}{l}\text { - The delivery of pharmaceutical care is affected by the way } \\
\text { of life of the communities served; } \\
\text { - In Nunavut, the unique culture and language of remote Inuit } \\
\text { communities present additional communication challenges, } \\
\text { which can result in drug-related adverse effects and lack of } \\
\text { interaction between practitioners and patients; } \\
\text { - Multi-method research is an effective strategy for } \\
\text { examining these complex issues and guiding future policy } \\
\text { initiatives to minimize challenges in Nunavut; } \\
\text { - The study suggests future directions for policies that will } \\
\text { improve the effectiveness of pharmaceuticals and health } \\
\text { care expenses for the Inuit in Canada. }\end{array}$ \\
\hline
\end{tabular}

SANTOS, M.M.H. (2015) "Pharmaceutical Assistance as a Structuring Strategy for the Promotion of the Rational Use of Medicines in Indigenous Health in Pernambuco: an economic approach".

SWAIN, L.; BARCLAY, L. (2015) "Medication reviews are useful, but the model needs to be changed: Perspectives of Aboriginal Health Service health professionals on Home Medicines Reviews".
Addresses the challenges of structuring and the impact of pharmaceutical assistance management on access to the rational use of medicines for Brazilian indigenous peoples, using an economic approach.

Identifies how the Australian Domestic Drug Review program could better serve the needs of Aboriginal people and Torres Strait Islanders.
- Access to medicines is directly related to the quality of the health service offered;

- Implementation of pharmaceutical assistance actions can optimize resources and improve the quality of assistance to the indigenous population.
- Aboriginal Health Services is well positioned to be a promoter, organizer, facilitator, and implementer of health programs, such as the Domestic Drug Review Program for Aboriginal and Torres Strait Islander clients.

- Incorporating pharmacists into indigenous health services faces many challenges in the Domestic Drug Review Program. However, the program ensures that pharmacists are culturally oriented and that they create strong relationships with health professionals and clients.

- The rules of the Domestic Drug Review Program need to be significantly changed if reviewing medications is to be a useful tool to improve drug safety and adherence for Aboriginal people and Torres Strait Islanders.

- Ethnic differences in attitudes towards medicines and drug taking are apparent, although there are some similarities in need regarding support and advice on the use of medicines. This will help inform the development of communication resources and tools to assist pharmacists in providing pharmaceutical assistance to diverse patient populations. towards Pharmaceutical Care among older people of indigenous peoples in New Zealand, the Pacific and Asia.

Discuss access to medicines by indigenous Australians, focusing on urban population expansion of the Session 100 program that allows direct dispensing by the prescriber at the time of the consultation.
- The expansion of the Session 100 program has increased access to the drug to the isolated Australian Indian population and its expansion to non-isolated populations may be beneficial in accessing the drug, but issues such as pharmaceutical orientation may be impaired as well as the enhancement of the pharmaceutical professional. communities - is expansion of Section 100 the answer?" 
Many studies did not make any relation with the object of interest; however, most, except those presented in Table 1, sought to understand, from the biomedical point of view, the mechanisms of the therapeutic resources of indigenous peoples in the world, as well as to scientifically investigate the plant and animal materials used by these peoples, employing known conventional methodologies. A range of studies addressed specific diseases through case studies, in which the main focus was the evolution of the disease or the western therapy applied to the indigenous subject, in an investigation format that tried to show different clinical responses to treatment and the outcome of the pathology.

The lack of information on evaluation and discussions in pharmaceutical assistance for the indigenous population is evidenced in this review. However is important to highlight that although no rich discussions or researches about pharmaceutical assistance for indigenous territories could be found, it does not mean that there is no Pharmaceutical Care in indigenous areas. This scenario reflects the gap in the political and scientific interest in the theme or due to a lack of investments in research or the insufficient attention given to this population segment, historically neglected.

The benefits of Indigenous Pharmaceutical Assistance go beyond those promoted by conventional Pharmaceutical Care. Although patient-centered and based on adequate, effective, and safe pharmacological treatment, Indigenous Pharmaceutical Assistance also considers all epidemiological, cultural, economic, and geographical aspects of the indigenous community (Faus, 2000). Therefore, adequate Indigenous Pharmaceutical Assistance can contribute to the autonomy and identity maintenance of traditional medicine while increasing access to conventional medicines and technologies by indigenous peoples.

The necessary care in the rationalization use of industrialized drugs and the considerations regarding ethnic and cultural issues for the provision of specific pharmaceutical assistance to indigenous people does not presuppose any negligence related to the health demands of these people or access, but a personalized service through the insertion of conventional medicine in a consented manner and based on the respect for traditional therapeutic conducts. It is only possible through the sensitization of the professional responsible for this Pharmaceutical Assistance, analyzing new contexts based on the conceptions of illness among indigenous people (Pellegrini, 1998; Pacini, 1999).

The pharmaceutical practice challenges, in a universal manner, although modified over time, have been maintained since their first citations, by Brodie et al. (1980), who defined Pharmaceutical Care as "the pharmacotherapeutic needs of a given patient and the provision not only of the required medications but also of the necessary services (before, during and after) to ensure a perfectly safe and effective therapy."

However, a major challenge in the indigenous health context and the provision of services involving Pharmaceutical Assistance is the neglect of the indigenous patient specificities and the focus on the availability and access to medication. Currently, Pharmaceutical Assistance considers the patient as the greatest beneficiary of the assisted and regulated cycle of medication; however, in the indigenous context, there is still much to be done, especially regarding the valorization of traditional medicine and the rational use of conventional medication (Cipolle; Strand; Morley, 2000).

Interactions between patients and medication are affected by language and culture. Prescription drug use varies with ethnicity and is influenced by different cultural beliefs and backgrounds. An example of this is the widespread diminished trust in the efficacy of pharmaceuticals among Asian patients (Horne, 2004; Morgan, 2011). Culture can affect attitudes and beliefs towards different types of illness in different groups or within the same communities. Chinese indigenous men's attitudes toward mental illness result in fewer antidepressant prescriptions than in non-indigenous men. Chinese Indigenous women's attitudes toward the same illness result in significantly fewer prescriptions than non-Indigenous women (Morgan, 2011).

Patients' motivations or desires for seeking medical assistance and healthcare access differ among various ethnic groups. 
Research, Society and Development, v. 10, n. 12, e478101220344, 2021

(CC BY 4.0) | ISSN 2525-3409 | DOI: http://dx.doi.org/10.33448/rsd-v10i12.20344

Medication use in children also differs with ethnicity (Hahn, 1995). Indeed, ethnicity can affect medication use in several ways: through prescription requests, beliefs about the effectiveness of prescription or OTC (Over The Counter) medications, or difficulty accessing pharmacy services.

The therapeutic tool historically used by Indigenous Peoples is Traditional Medicine, defined by the World Health Organization (WHO) as the sum of knowledge, skills, and practices based on the theories, beliefs, and experiences peculiar to different cultures, whether explicable or not. Moreover, WHO recognizes Traditional Medicine as a tool used for health maintenance, diagnosis, treatment, and cure physical and mental illnesses (WHO, 2019).

Since the Declaration of Alma-Ata, the WHO has joined efforts to incorporate Traditional Medicine into Public Health Services (WHO, 1978) and, with few practical advances in countries, it still carries out mechanisms to protect and strengthen Traditional Medicine. In this effort, the "WHO Strategy on Traditional Medicine 2002-2005" (WHO, 2002) and its updates (WHO, 2013) bring directives about policies, safety, quality and efficacy, access, and rational use of traditional medicines. Also, the topic on Traditional Medicine in the "Pharmaceutical Strategy 2004-2007" manual (WHO, 2004) recommends access, intellectual property rights protection, and traditional medicines safety, efficacy, and quality.

The current WHO recommendations are based on harnessing the potential contribution of Traditional and Complementary Medicine to health, well-being, and people-centered health care and promoting the safe and effective use of Traditional and Complementary Medicine through regulation and research, as well as by incorporating products, practitioners, and practices into health systems in an appropriate manner (WHO, 2013).

D'Souza (1993) presented the historical benefits of the use of Traditional Medicine in remote rural areas, in which it was often the only therapeutic source for the demands of the health-disease process. Her study was conducted in an Indian area in the Dhule district of Maharashtra, India, among the Bhils, Koknas, and Vanjaras. The author highlighted the constant exploitations suffered by the indigenous people, over the years, in the fields of Education, Health, and Agriculture, and because of this, these people had a strong resistance to contact with other social strata.

According to WHO, more than 50\% of all medicines globally are prescribed, dispensed, sold, and used incorrectly (WHO, 2010). The same situation is observed for the vast majority of indigenous communities: little investment in Pharmaceutical Assistance and rational use of medicines fields, by the various professionals inserted in the most distinct types of health systems.

Indigenous populations have experienced a history of cultural and linguistic persecution that has threatened and even annihilated numerous indigenous languages, as well as a wide array of traditional practices and knowledge. While it is uncertain that these factors have contributed to health disparities, it is widely acknowledged that cultural discord and lack of integration with Westernized health systems play an important role in this (Romain, 2013).

It remains to be seen what the consequences and the real relationships between access to biomedical services and the exercise of traditional health systems are, as well as the mechanism that has led to the weakening of traditional practices within the indigenous context, especially involving conventional medicine and its relationship to the preservation of cultural identity. Studies evaluating the relationship between the expansion of industrialized medicine in the context of Indigenous health have been necessary. For example, a survey evidenced that the lack of access to the conventional system influences the application of Traditional Medicine in Africa, Asia, and Latin America, where about half of the population has little access to high-quality biomedical services and relies on traditional health systems (Hitziger et al., 2017).

Traditional therapies are still the main or the only source of health for millions of people worldwide (WHO, 2013). Considering this, Pharmaceutical Care must appropriate ethnic and ethnopharmacological knowledge to provide adequate care to the 
different intercultural contexts in the world.

Researchers examining the relationship between traditional medicine and biomedicine have observed two conflicting trends. One strand suggests that the biomedicine and biomedical concepts use displaces traditional medicine and medical beliefs. The contested relationships between conventional and informal medicine have a deep provenance, and as scientific medicine began to professionalize in the 19th century, traditional health knowledge and practices were simultaneously absorbed and unemployed (Porter; Crosby, 1998).

Other researchers, meanwhile, have found that traditional medicine and conventional medicine can coexist, complement each other, and mix (Giovaninni et al., 2011). Using an econometric model and quantitative data to test the association between personal knowledge of pharmaceuticals and personal knowledge of medicinal plants, they observed a significant positive association between individual knowledge about medicinal plants and their use and knowledge about the use of pharmaceuticals in a survey involving 136 household heads from a rural indigenous community region in Oaxaca, Mexico. The authors concluded that the use of plants for curative purposes and conventional medicines coexisted and complemented each other.

An ethnographic study by Yajahuanca et al. (2015) at San Regis community on the Marañon River in Loreto, Peru, examined the cross-cultural correspondences and inequalities affecting vulnerable population groups in their interactions with health services. The study found a preference for traditional treatment and found that the choice was due to the close relationship between the healer and the sick person.

Around the world, indigenous peoples have defended their right to maintain their cultural beliefs and traditional medicine practices. In 2007, more than 370 million people representing 5,000 distinct groups worldwide received global recognition by adopting the United Nations Declaration on the Rights of Indigenous Peoples. Article 24 of UNDRIP affirms the rights of indigenous peoples to their traditional medicines and health practices and all health and social services. Although not a legally binding agreement, UNDRIP encourages nation-states to comply with and implement measures to support and maintain its provisions. However, the difficulties that permeate its adoption go beyond those set in the cultural realm (UN, 2007)

The challenges of Pharmaceutical Care in the world go beyond symbolic and scientific barriers between the traditional and conventional models. Indigenous health care was considered a threat to the conventional health care system in South Africa (Nemutandani et al., 2016). Traditional practices and knowledge were associated with "witchcraft," generating popular discouragement and suppressing prohibition laws. The introduction of the Traditional Health Practitioners Act No. 22 (South Africa, 2007) succeeded in strengthening the traditional medicine system by establishing an Interim Council of Traditional Health Practitioners of South Africa.

However, the studies conducted by Nemutandani et al. (2016) concluded that conventional health professionals did not seem ready to work with traditional health professionals, citing challenges of quality of care, differences regarding the concept of sciences, and source of knowledge. Health professionals involved in care processes for the indigenous population deserve attention for a humanized training, sensitive to the peculiarities of different indigenous peoples and in the distinct intercultural contexts, considering that the use of pharmaceuticals alone is not associated with a decline in knowledge and use of medicinal plants (Giovaninni, et al. 2011).

\section{Conclusion}

There is little published academic or governmental research on Pharmaceutical Assistance aimed at the Indigenous context in the world, despite the considerable public expenditure at global and territorial levels on pharmaceutical products and their 
importance to health care delivery. Different responsibilities influence the actions of Indigenous Pharmaceutical Assistance; however, respect for the differentiated lifestyle of indigenous peoples is crucial for personalized care in harmony with both the biomedical and other therapeutic models. Indeed, it should be the central axis for any Pharmaceutical Assistance action or program involving indigenous peoples worldwide.

Addressing the issues that involve the planning, implementation, development, and evaluation of Indigenous Pharmaceutical Assistance is necessary in the current times for the future development of policies, can result in cultural and economic benefits throughout the system, as well as harmony in the combination of therapeutic models, traditional and biomedical, which will lead to better patient compliance and lower risk for the communities. Besides the extreme need to insert the Pharmacist in the health teams that provide care to indigenous people, it is necessary to have adequate professional training to act in an intercultural context. Health professionals must identify issues that need attention and benefit the demands of the health sector ethically and fairly. These should be the concerns of Indigenous Pharmaceutical Assistance.

The challenges that permeate the field of Indigenous Pharmaceutical Assistance in the world still hinder important advances in this field, such as communication, limited geographical access in areas of difficult access, lack of continuous training to act in an intercultural context, absence or insufficient political and economic attention from the public sector, cultural conflicts established by the lack of understanding of health professionals, among others.

The guarantee of medicines in symbiosis with the traditional health practices of indigenous peoples, which involve the knowledge and use of medicinal plants and other traditional customs used in the treatment of diseases and other health problems, is the biggest challenge to the professionals who deal directly and daily in the villages.

The pharmacological relationship between Western and Traditional Medicine is unknown, and little is being studied. What would be the interactions, synergy, symptomatic coverage, and biochemical interaction of this composition? Understanding this complex connection perhaps is the best way to preserve the culture of indigenous peoples. It is necessary to guarantee the autonomy of these peoples to carry out or authorize surveys and the dissemination of traditional habits and customs, knowledge, and therapeutic practices, promoting respect for the guidelines, national policies, and legislation regarding genetic resources, bioethics, and the intangible assets of traditional societies.

Finally, the findings of this review can awaken scientific interests, as well as help to achieve better results in the application of Pharmaceutical Assistance for Indigenous Peoples, regarding the process of understanding the need for trained professionals, a fundamental requirement for the construction of a solid Indigenous Pharmaceutical Assistance worldwide, capable of considering each territory, as a way to move forward and overcome the challenges that still prevail and hinder the construction and development of indigenous health worldwide.

\section{References}

Bassett-Clarke, D., Krass, I., \& Bajorek, B. (2012). Ethnic differences of medicines-taking in older adults: a cross cultural study in New Zealand. Int J Pharm Pract. 20 (2), 90-98. 10.1111/j.2042-7174.2011.00169.x.

Brazil. Ordinance 3916 (1998). National Medicines Policy. Brasilia: Ministério da Saúde. https://bvsms.saude.gov.br/bvs/publicacoes/politica_medicamentos.pdf

Brodie, D. C., Parish, P. A., \& Poston, J. W. (1980). Societal needs for drugs and drug-related services. Am J Pharm Educ, 44 (3), $276-278$.

Cipolle, R. J, Morley, P. C, \& Strand, L.M. (2000) The exercise of pharmaceutical care. McGraw-Hill Interamericana

Bassett-Clarke, D., Krass, I., Bajorek, B, Ethnic differences of medicines-taking in older adults: a cross cultural study in New Zealand, International Journal of Pharmacy Practice, 20, 90-98, https://doi.org/10.1111/j.2042-7174.2011.00169.x

D'Souza, M. (1993). Health and indigenous development. Health millions. 1 (3), 6-7. 
Research, Society and Development, v. 10, n. 12, e478101220344, 2021

(CC BY 4.0) | ISSN 2525-3409 | DOI: http://dx.doi.org/10.33448/rsd-v10i12.20344

Faus, M.J. (2000). Pharmaceutical Care as a Response to a Social Need. Ars Pharm. 41 (1), 137-143

Giovaninni, P., Reyes-García, V., Waldstein, A., \& Heinrich, M. (2011). Do pharmaceuticals displace local knowledge and use of medicinal plants? Estimates from a cross-sectional study in a rural indigenous community, Mexico. Soc Sci Med 72 (6), 928-936. 10.1016/j.socscimed.2011.01.007.

Hahn, B. A. (1995). Children's health: racial and ethnic differences in the use of prescription medications. Pediatrics. 95 (5),727-732.

Hernández, A., Ruano A. L, Marchal B., San Sebastián M., \& Flores W. (2017). Engaging with complexity to improve the health of indigenous people: a call for the use of systems thinking to tackle health inequity. Int J Equity Health. 16(1):26. 10.1186/s12939-017-0521-2.

Hitziger, M., Gonzalez, M. B., Gharzouzi, E., Santizo, D. O., Miranda, R. S., \& Ferro, A. I. A. (2017). Patient-centered boundary mechanisms to foster intercultural partnerships in health care: a case study in Guatemala. J Ethnobiol Ethnomed 13(1), 44. 10.1186/s13002-017-0170-y

Horne, R., Buick, D., Fisher, M., Leake, H., Cooper, V., \& Weinman, J. (2004). Doubts about necessity and concerns about adverse effects: identifying the types of beliefs that are associated with non-adherence to HAART. Int J STD AIDS. 15(1), 38-44. 10.1258/095646204322637245

ILO. Indigenous and Tribal Peoples Convention 169 (1989). International Labor Organization. https://www.ilo.org/dyn/normlex/en/f?p=NORMLEXPUB:1210 0:0::NO::P12100_ILO_CODE:C169

Morgan, G. Reflections on images of organization and its implications for organization and environment. Organization \& Environment. 2011;24(4):459-78.

Nemutandani, S. M., Hendricks, S. J., \& Mulaudzi, M. F. (2016). Perceptions and experiences of allopathic health practitioners on collaboration with traditional health practitioners in post-apartheid South Africa. Afr J Prim Health Care Fam Med. 8 (2):1-8. 10.4102/phcfm.v8i2.1007

Pacini, A. Pacify: interethnic relations and terriorization of the Rikbaktsa: Dissertation (Master in Anthropology), National Museum, Federal University of Rio de Janeiro, Rio de Janeiro, 1999. http://www.comin.org.br/news/publicacoes/1282915485.pdf.

Pellegrini, M. Talking and eating: a study on the new contexts of falling ill and seeking treatment among the Yanomamè of Alto Parima. 1998.

Porter, R., \& Crosby, A. W. (1998). The Greatest Benefit to Mankind: A Medical History of Humanity from Antiquity to the Present. Fontana Press. 1998.

Romain, S. J. (2013). Pharmaceutical health care and Inuit language communications in Nunavut, Canada. Int J Circumpolar Health. 72 (1), 21409. 10.3402/ijch.v72i0.21409.eCollection 2013

Santos, M.M. H. Assistance Pharmaceutical as a Structuring Strategy for the Promotion of rational use of medicines in the Indigenous Health of Pernambuco: an economic approach. APS magazine. 2015;18(2).

South Africa. Act 22 (2007). Traditional Health Practitioners. https://www.gov.za/documents/traditional-health-practitioners-act

Stoneman, J., \& Taylor, S. J. (2007). Improving access to medicines in urban, regional and rural Aboriginal communities-is expansion of Section 100 the answer? Rural Remote Health. 7 (2), 738.

Swain L., \& Barclay L. (2015). Medication reviews are useful, but the model needs to be changed: Perspectives of Aboriginal Health Service health professionals on Home Medicines Reviews. BMC Health Serv Res 15 (1), 366. 10.1186/s12913-015-1029-3

UN. (2007) United Nations Declaration on the Rights of Indigenous Peoples. Genebra: Department of Economic and Social Affairs. https://www.un.org/development/desa/indigenouspeoples/declaration-on-the-rights-of-indigenous-peoples.html

WHO (1978). International Conference on Primary Health Care. Alma-Ata Declaration, USSR, 1978.

WHO (2010) The World Health report. Health System Financing: the path to universal coverage. World Health Organization. https://cdn.who.int/media/docs/defaultsource/health-financing/technical-briefs-background-papers

WHO (2019). Global report on traditional and complementary medicine. Genebra: World Health Organization, https://apps.who.int/iris/bitstream/handle/10665/312342/9789241515436-eng.pdf

WHO. (2002). Estrategia de la OMS sobre medicina tradicional 2002-2005. World Health Organization.

WHO. (2004). Pharmaceutical Strategy 2004-2007. World Health Organization, 2004.

WHO. (2010). Medicines: rational use of medicines. Fact sheet. 2010 (338).

WHO. (2013) Estrategia de la OMS sobre medicina tradicional 2014-2023. World Health Organization.

Yajahuanca, R. A., Diniz, C. S. G., \& Cabral, C. S. (2015). We need to "ikar the kutipados": interculturality and health care in the Peruvian Amazon. Ciencia Saude Colet. 20 (9), 2837-2846. 10.1590/1413-81232015209.13712014 